\title{
Humanist Limits in the Material Phenomenology of Religion
}

\author{
Gaelin Meyer \\ gaelinmeyer@me.com
}

\begin{abstract}
This article tracks a shared methodological tension within the work of a few classic phenomenologists, based on an epistemological juxtaposition at the heart of their enquiry. This epistemological tension emerges as secular and non-secular concepts are worked with concurrently. A modified form of this tension is present in the materialist phenomenology of religion that David Chidester presents, which links his phenomenology to the earlier classical forms. However, although a methodological tension is maintained in his work, the epistemological juxtaposition that initiated the tension is collapsed along humanist boundaries, with important consequences for the study of religion.
\end{abstract}

Keywords: Religion, epistemology, materialism, phenomenology, humanism, science, reducibility, systems, contact zones

\section{Introduction}

The phenomenology of religion is understood to be a heterogenous field of enquiry and its many differing methods and frameworks have been contested and critiqued, both by those who identify with the field and by critics from other disciplines. That said, there is an important and overlooked similarity between a few of the leading thinkers. There is specifically a significant methodological tension within the work of Pierre Chantepie de la Saussaye ${ }^{1}$,

1 Pierre Chantepie de la Saussaye was a thinker who first proposed a religious phenomenology, while his father, Jacques Georges Chantepie de la Saussaye, was 


\section{Gaelin Meyer}

Gerardus van der Leeuw, and Ninian Smart, based on an epistemological juxtaposition at the heart of their enquiry. The work of these scholars contains a tension between 'religion itself' as an irreducible domain, and the reductive scientific methods applied to its examination. The two positions are that of the religious insider ${ }^{2}$ who works with religion as a sui generis reality, and that of the religious outsider, as characterized by a secular scientific enquiry. While these early phenomenologists of religion maintained the validity of the religious insider's position, there is also an attempt to satisfy religious outsiders with the use of reductive scientific methods. As will be discussed below, the application of inductive reasoning to the empirical facts (or objects) of religion forms the basis of their enquiry. This reflects their commitment to the growing secular ${ }^{3}$ epistemology that Western humanism brought to bear in the $20^{\text {th }}$ century, in which empirical accounts of phenomena were prioritized.

Chantepie, Van der Leeuw, and Smart all attempted to negotiate a position between the transcendent frame of Western theology and the immanent frame of science. This leads to a comparative method. Religious phenomena as objects can be unified and compared in the same horizon as both religious and empirical, only because they share an 'essence' of some kind which then permits this comparison. Chantepie, Van der Leeuw, and Smart present a secular field of study that is only achievable through an epistemological tension between the insider's and the outsider's position. That said, the phenomenology of religion did not end at the close of the $20^{\text {th }}$ century but is reimagined by the early material theorist David Chidester. Despite Chidester's attempt to move the phenomenological discussion into the realm of secular materiality, he retains a tension between the

also a widely published theologian. In this text I will refer to Pierre only as Chantepie, as done by Van der Leeuw in his Religion in essence and manifestation (Van der Leeuw 1986).

2 I am adopting Russel McCutcheon's use of the terms 'insider' and 'outsider', which refer to the general positions held by those who participate in religious behaviors and beliefs, and those who do not (McCutcheon 1999:2).

3 In this regard, I refer to Charles Taylor's discussion (Taylor 2007) of secularity as an epistemological move towards a self-sufficient humanism, which entails a rejection of metaphysics in favor of an empirical frame of reference for the study of human affairs. 
'irreducibility' of religion and the reductive methods of modern science, by presenting the lived experience of the human body as the horizon which unifies the 'religious' and the empirical. Through this move, he resolves the longstanding epistemological juxtaposition by relocating the 'irreducibility' of religion to within a bounded material dynamic. By deconstructing metaphysical irreducibility, Chidester's material phenomenology undermines the position that classical phenomenology attempts to maintain between the secular and the non-secular.

\section{Dual Epistemological Commitments in Classical Phenomenology of Religion}

Chantepie (1848-1920) was the first scholar to call himself a 'phenomenologist of religion' . He took his phenomenological method from John Robison, a British empirical scientist and philosopher. Robison defines phenomenology as 'the complete or copious narration of facts, properly selected, cleared of all unnecessary and extraneous circumstances, and accurately narrated' (Robison 1798:587). Accordingly, Chantepie's scientific phenomenology involves a 'collecting and grouping of various religious phenomena' (Chantepie de la Saussaye 1891:8) according to similarities, from data that are manifest, objective, and historical. He focuses on key phenomena that he understands as repeating themselves within different cultures, time frames, and traditions. For his description of the phenomena of religion, he has created categories that he deemed as universal, like 'objects of worship', 'the gods', 'sacred places', and 'religious times', and carefully divided up the many historical 'facts' that history has provided him.

Chantepie also followed Robison's directions regarding the further explication of phenomena. For Robison, after the 'phenomenology' (or description) of an event is attained, inductive taxonomic reasoning is applied. In Chantepie's work, the 'facts' of religion are taken out of their historical context and are amassed by a reduction to categories. In attempting a late

4 Chantepie's use of the term 'phenomenology' differs markedly from Hegel's definition and method, and Kant's phenomenon versus noumenon, although Chantepie cites both these thinkers in the course of his writing. 


\section{Gaelin Meyer}

$19^{\text {th }}$-century science of religion ${ }^{5}$, Chantepie necessarily engages in a process of methodological reduction. The useful and necessary reductions employed in the sciences are responsible for important theories and advances.

However, Chantepie couches his reduction of religious 'facts' within a broader 'non-reductive' scope of study. He does this on dual grounds, appealing to both the 'non-reducible' nature of religion within the academy, and the 'non-reducible' nature of religious 'essence'. From the viewpoint of academic study, staking a claim to a 'non-reducible' field of enquiry, is a necessary step for a burgeoning science. 'Like biology's claim to be autonomous over against the reductions of chemistry and physics' (Pals 1999:188), a non-reductive framework for the study of religion preserves the field itself as significant in its own right. For Chantepie's phenomenology of religion to exist as a distinct disciplinary approach, the domain of 'religion' itself needed to remain irreducible in some manner or form as with the other scientific domains. However, he also resists the ontological reduction inherent in the naturalist, scientific approach. In this regard, he uses a reductive scientific method to explicate, not eliminate, categories like 'the gods' that are important to religious believers. His resistance to an ontological reductionism is a rejection of the positivism that would explain religion in purely naturalist terms. This trend, also visible in the work of Van der Leeuw and Smart, provides the grounds for critics to dismiss the phenomenology of religion as a thinly veiled Protestant theology.

It is in Chantepie's definition of religion that this epistemological juxtaposition is most clear. Adding to E.B. Tylor's definition (religion as 'the belief in Spiritual Beings' (Tylor 1903:424), Chantepie defines religion as 'a belief in superhuman powers combined with their worship' (Chantepie de la Saussaye 1891:71). When it comes to a discussion of the many objects of worship he has encountered in his studies, he makes no claims regarding whether this worship is due to 'the material object itself, or an indwelling spirit, or the divine power revealed in it' (Chantepie de la Saussaye 1891:71). However, he acknowledges that, for some scholars of religion, there is 'in reality but one object, the living God who manifests Himself among all nations as the only real God' (Chantepie de la Saussaye 1891:71), which he

5 His phenomenological contribution can be found within his book titled Manual of the science of religion (Chantepie de la Saussaye 1891). 
finds problematic. He writes that a scientific study of religion must acknowledge many 'different objects of belief and of worship' even though it is 'not easy to say how we can define these objects in general' (Chantepie de la Saussaye 1891:72). This sets his project apart from the theological focus on particulars. According to Chantepie, theology, 'which has for its object true religion only' (Chantepie de la Saussaye 1891:10) differs substantially from his science of religion (Chantepie de la Saussaye 1891), which examines religious 'facts' from all over the world and from many different religious traditions. Yet his phenomenology presents a 'secular' field of study that attempts to maintain a relevance for Christian theology (Chantepie de la Saussaye 1891:v) and as a result he employs a hybrid secular and non-secular epistemology to ground his examination. His overall focus is on categorizing the 'outward forms of religion' (i.e. manifest, empirical phenomena) according to a scientific method, but he understands them in terms of 'inward processes' which distinguish 'religious acts, ideas, and sentiments' from 'non-religious acts, ideas and sentiments' (Chantepie de la Saussaye 1891: 67). His phenomenology is both a technique of empirical classification and an idealized apprehension of religious essence ${ }^{6}$. He writes about the importance of the "qualitative judgment which has to determine "the religious sphere", (Chantepie de la Saussaye 1891:67), while simultaneously attempting a quantitative and scientific enquiry into religion. He has founded the field of 'phenomenology of religion', and although he is mostly forgotten in the literature, the tension that he has established is visible throughout the development of the field. That his phenomenology was a method for the science of religion was something he went out of his way to establish, and with that he claims the objectivity and universal access of the $19^{\text {th }}$-century scientist.

However, Chantepie retains a commitment to two different 'ways of knowing'. The two opposing epistemologies at work in his project create a methodological tension, a phenomenology of religion that involves the application of reductive methods to an irreducible phenomenon. This epistemological juxtaposition is purposefully maintained in his work, in order

6 His use of the term 'essence' in his Manual (Chantepie de la Saussaye 1891) can be traced back to his readings of Hegel, Schleiermacher, and Kant, whom he credits with providing the foundations for a science of religion. 


\section{Gaelin Meyer}

to present a study that attempts to be accessible to both secular and nonsecular thinkers. This necessary methodological move initiated a new field, a study of religion which is neither a simply secular science nor a theological endeavor, but which attempts to build a bridge between the two.

Van der Leeuw, who writes as a successor to Chantepie, notes that 'phenomenology is the systematic discussion of what appears. Religion, however, is an ultimate experience that evades our observation, a revelation which in its very essence is, and remains, concealed' (Van der Leeuw 1986: 683). Like Chantepie, Van der Leeuw is interested in a science of religion that preserves the objects of religion but is not a theology. To achieve this, he applies a reductive methodology to categorize the data of religion, treating religion itself as an 'object' of empirical investigation. He has also inherited Chantepie's notion of religion as ultimately non-reducible, in both of the ways that Chantepie intended: First, he adheres to Chantepie's domainpreserving irreducibility. He echoes Chantepie's commitment to studying religion as a distinct category in itself and not as an adjunct to sociological or psychological enquiry (Van der Leeuw 1986:686). Second, and in a more complicated manner, he has inherited Chantepie's posited metaphysical irreducibility - a commitment to the notion of a world divided into 'essence' and 'manifestation' (Van der Leeuw 1986:683), in which religion is the manifestation of an essence which itself is not directly accessible.

However, Van der Leeuw mentions a number of times that his phenomenology is not a metaphysics (Van der Leeuw 1986:675), but an attempt at an objective description of the phenomena of religion. This objectivity reflects the epistemological stance of the empirical scientist, granting him the possibility of legitimacy within the secular academy. Van der Leeuw's phenomenology, like Chantepie's, attempts a hybridization of non-secular and secular positions. The abstract and/or subjective aspects of religious phenomena are reduced to objects, and through this, 'the empirical, ontal or metaphysical fact becomes a datum' (Van der Leeuw 1986:676; original emphasis). Van der Leeuw does not perform an eliminative reduction of the religious 'objects' that generate his data. Rather, he maintains that 'the first affirmation we can make about the Object of Religion is that it is a highly exceptional and extremely impressive "Other" (Van der Leeuw 1986: 23; original emphasis). He also stakes a claim for the study of religion outside of theology. Like Chantepie, he attempts to take the study of religion into a scientific discourse by separating himself from a theological enquiry. $\mathrm{He}$ 
emphatically states that his 'phenomenology of religion is not theology' (Van der Leeuw 1986:687). Instead, he defines the object of his phenomenological study as 'the activity of man in his relation to God' (emphasis added), and 'that "God" is frequently an extremely indefinite concept which does not completely coincide with what we ourselves usually understand by it' (Van der Leeuw 1986:23). In order to study this 'other', Van der Leeuw examines the physical outworkings of its presence, which he attributes to a power that can be 'authenticated (or verified) empirically' (Van der Leeuw 1986:25). In this regard, he argues that the 'essence' or 'source' of religious revelation itself is irreducible, but that the human experience of this revelation can be reduced to an empirical phenomenon, being addressed in a scientific manner. He writes that, when it comes to religion, his focus is on the intelligible experience of religion, as 'man's reply to revelation, his assertion about what has been revealed, is also a phenomenon from which, indirectly, conclusions concerning the revelation itself can be derived' (Van der Leeuw 1986:679). By separating essence from manifestation, he attempts to lay the ground for a reductive scientific appraisal of the empirical (manifest) aspects of religion, while still preserving the underlying 'essence' of religion as irreducible.

Both Chantepie and Van der Leeuw wrote at a time in history when the authority and jurisdiction of religious thinking was challenged by the rigors of scientific thought. Neither wanted to have religion 'dissolved' into other categories of enquiry, as if the phenomena associated with religion were only relevant in relation to other, more fundamental aspects of human experience. With religion guarded as an academically irreducible realm of examination, the role of the phenomenologist of religion can take shape. Van der Leeuw writes that 'the phenomenology of religion is not the history of religion...the phenomenology of religion is not a psychology of religion...the phenomenology of religion is not a philosophy of religion' (Van der Leeuw 1986:108-109). Rather, as religion cannot be reduced to 'history' or 'psychology', the phenomenologist takes his place alongside the other sciences and focuses on 'religion itself' as the privileged object of study.

This domain-preserving irreducibility regards 'religion' as a distinct and necessary category of enquiry, not reducible to a mere epiphenomenon of history, sociology, or psychology. However, it is an objectified version of religion that is preserved. This version of religion reduces the complex phenomena of religion to objects, and then reifies these 'objects' to form the basis of a scientific enquiry. This is a solution that is not satisfying to either 


\section{Gaelin Meyer}

secular or non-secular thinkers. Van der Leeuw's phenomenology is a good example of the methodological tension that arises from this continued epistemological juxtaposition. His phenomenology, although it differs from Chantepie's in some important ways, ultimately involves the application of reductive methods to an irreducible phenomenon. This has been a source of much criticism, as later thinkers have responded by attempting to collapse the juxtaposition entirely. However, it is my contention that these classic phenomenologists purposefully maintained an epistemological juxtaposition in order to present a study of religion that attempts a very difficult goal, to be accessible to both secular and non-secular thinkers.

Smart writes at the end of the 'golden era' of the phenomenology of religion - an era which extends from Chantepie's first publication in the field, to the latter part of the $20^{\text {th }}$ century - as the classic approach was being contested and renegotiated by later thinkers. He contributes to the discussion that Chantepie has begun and builds further on the work of Van der Leeuw, in an attempt to further develop both the science of religion and the phenomenological approach to the study of 'religion' as a distinct phenomenon. Despite the developments that Smart introduces to the phenomenological process, his work also contains the same implicit tensions. He writes that 'there is a contrast between doing theology' (which he describes as 'articulating a faith') and the study of religion itself, for which 'theology is part of the phenomenon to be understood' (Smart 1973:7). However, although he presents a secular science of religion ${ }^{7}$, he includes a sentimental component, the 'sensitive and artistic heart' that he proposes as necessary. Smart, like Chantepie and Van der Leeuw, feels that the 'dialectical relationship...between the study of religion and theology is most important' (Smart 1978:11). He was accused of theological leanings, despite his protestations, and his attempts at basing his examination of religion in the methods of science has also seen him dismissed by theological thinkers as an 'outsider' with no meaningful access to religious phenomena. In his book, The phenomenon of religion (Smart 1978), Smart defends his position against the criticisms of both sides of the epistemological divide, acknowledging that 'an overall strategy of a science of religion...has not yet been fully worked

7 See his book, The science of religion and the sociology of knowledge (Smart 1973) for more on his scientific approach to the study of religion. 
out' (Smart 1978:4). He addresses religious readers by assuring them that a scientific study of religion need not 'reduce religion away' (Smart 1973:3), and he also attempted to locate his study in the secular sciences, by insisting on 'methodological agnosticism' (Smart 1978:57) which makes no theological claims.

On the whole, those who have opposed reductionism have tried to do so by establishing the actuality of the divine or of the Holy. They take as it were a step into theology. By contrast, I wish here to establish a method of looking at the objects of religious experience and belief which neither brings heaven down to earth nor takes a step into metaphysics and theology (Smart 1973:49).

Smart admits a lofty goal. He attempts to plot a position between 'heaven and earth', between the immanent and the transcendent frame, in order to avoid reductionism on the one hand, and to refrain from 'establishing the actuality of the divine' on the other. It is a goal that is highly contested, and the outcome of his phenomenology was an uneasy methodological tension that displeased both secular and non-secular thinkers. The objectivity that he attempts to apply to his investigation, forms part of an epistemology that works with true/false assumptions (the scientific paradigm). His unwillingness to comment on the truth or falsity of religious claims displeased the secular academy. However, objectivity as verification is not what he intends when he appeals to a scientific method to organize his enquiry. He is rather attempting an objective assessment of an object from a different epistemological horizon - the transcendent object of religion, understood in a non-secular sense to designate an essential holiness or sacred property. Like Chantepie and Van der Leeuw before him, his phenomenology rests on an epistemological juxtaposition, purposely put into place in order to maintain a position between the secular and non-secular modes of thinking.

However, he also critiques the reduction of religion to 'static' categories in the works of Van der Leeuw and Chantepie. Instead, he discerns 'patterns of change' (Smart 1996:7) within the historical data that he studies, and provides a framework for exploring dynamic categories within the study of religious phenomena. This opens up his study of religion to phenomena that play out over time, allowing the metric of duration to become part of his 


\section{Gaelin Meyer}

overall analysis. The reduction of religion to essentialized and unchanging 'facts' by Chantepie and Van der Leeuw is addressed in this move.

Smart's focus shifts more towards the human domains that impact (and are impacted by) religion, domains that show the character of interrelationality and change over time. In this move Smart is bringing history into focus as a process, and not as static. Rather than appealing to some unchanging religious reality at the base of his examination, he bases his phenomenological study on the changes that manifest through history. He does this in response to the current in Western thought that had begun to problematize the static essentialism of earlier thinkers. In response, he regrounds his examination of religion in the empirical aspects of dynamic religious practice. By focusing on 'the modes and forms in which religion manifests itself' (Smart 1996:7), he examines the 'incarnated worldviews' of religious believers (Smart 1996:3). Yet, while he writes that 'the aim is objectivity', this objectivity is in service of his bid 'to testify to what is experienced - to the essence or essences which are manifested' (Smart 1986:xi). His reductive scientific study of religious 'objects' relies on these objects being both empirical and religious in some essential and irreducible way - a tension that did not sit well with his critics. However, that is not to say that a position in-between these opposing epistemologies is impossible to attain, or that this goal is erroneous. I rather take his failure as a failure on behalf of the methods and insights of his time. These methods and insights were updated by David Chidester, who dedicated his book, Savage systems (Chidester 1996) to Smart; he was also a student of Smart at the University of California, Santa Barbara, in the 1970s. Furthermore, Chidester acknowledges Smart as profoundly influential in his latest publication Religion: Material dynamics (Chidester 2018).

\section{Material Phenomenology of Religion}

The work of Chidester is a good example of religious studies as a discipline examining itself and finding its basic principles wanting. The skewed power dynamics involved in the exchange between researcher and the research subject started coming to light as the century progressed. Chidester has demonstrated that many of the tropes of religious studies (the categories of the phenomenology of religion included) displayed hegemonic biases and 
contained vast aporias. However, despite Chidester's attempt to move the phenomenological discussion forward, he retains a tension between the 'irreducibility' of religion and the reductive methods of modern science. In Word and light (Chidester 1992), he presents the lived experience of the human body as the horizon which unifies the 'religious' and the empirical. As has already been stated, for the classic thinkers, religious phenomena as objects can be unified and compared in the same horizon as both religious and empirical, only because they share an 'essence' of some kind which then permits the comparison. This was also the undoing of the classical phenomenology of religion, as the end of the $20^{\text {th }}$ century saw a deconstruction of ideas around essence, universality, and the power it takes to maintain these structures. In this regard, Chidester's phenomenology of perception saves the phenomenological project, as it relocates the phenomenological description to the domain of the accessible material body: "Not merely a science of the senses, a phenomenology of perception locates consciousness and cognition in their experiential context, in a network of relations generated and sustained by human embodiment' (Chidester 1992:8).

Chidester's turn to the material body undoes the need for an 'essential' reality behind or within the 'manifest' reality of the natural world. In this regard the turn to the lived experience of the human body rescues the phenomenology of religion from criticisms around its complicated epistemological stance. Chidester has attempted to ground the longstanding epistemological ambivalence of his predecessors. His phenomenology of perception describes the immanent domain of bodily perceptions as the basis for the religious insiders' claim to the experience of 'transcendence'.

In turning to the human body as the ground of his examination, he relies on the empirical aspects of religious phenomena (i.e. the experience of the senses), which grants him a de facto objectivity, associated with a turning away from the metaphysics of transcendence towards the ground of the empirical, material world. However, Chidester also presents his phenomenology of religion as being based on an 'irreducible' reality, that of the experience of 'being embodied's. In this regard his phenomenology of reli-

8 In his Phenomenology of perception, Merleau-Ponty discusses the experience of the body as an experience of a certain kind of wholeness, not reducible to mere physiology or pure intersubjectivity (Merleau-Ponty 1962). 


\section{Gaelin Meyer}

gion contains the same praxis as the other thinkers that I have considered so far: He presents a non-theological field of study of the phenomena of religion, unified by their relations. However, in Chidester's case, these relations are embodied relations, not essential or metaphysical by nature. In other words, the universality of the human body becomes the basis for the unification of the religious facts that he examines in his enquiry. In this way, his early phenomenology of religion retains the tension between a reductive method and an irreducible ground of enquiry. However, what is lost in the movement from a metaphysical irreducibility to an embodied irreducibility is the commitment to the metaphysical categories that Chantepie, Van der Leeuw, and Smart have kept open. Although this loss is intentional, in as much as Chidester was trying to ground phenomenology in a material enquiry rather than a metaphysical one, the implications of this move have not been fully explored.

Chidester's turn to a material phenomenology introduces a definitive epistemological horizon by locating the phenomena of religion within the confines of the human body. In this regard, material phenomenology of religion stands the risk of being an eliminative venture, reducing the categories of religion in a way that eliminates them entirely and therefore compromises the irreducibility criteria required to preserve a relationship with the domain-preserving irreducibility of the field in general.

Chidester's project in Word and light (Chidester 1992) is to use the language of bodily perception to ground the transcendent metaphors that reflect religious experience. By relocating transcendence within a material frame, he is not fully disposing of the category, but attempting an ontologically conservative theory change, in which transcendence is not eliminated entirely, but rather identified with a phenomenal range that falls within the material. However, this move towards relocating the transcendent within the material, introduces the basis for an ontologically radical theory change, one which eventually leads to the elimination of the 'objects' of religion in regard to their association with anything not located in 'material reality'. By reducing the experience of religion to the examination of the human body, Chidester initiates a turn in the phenomenology of religion that orients it towards a completely different domain - the domain of material studies. His early phenomenological project reduces religious phenomena to the dynamics that can be tracked within the boundaries of 'the space between the body and symbolic discourse' (Chidester 1992:28). 
Soon after Word and light (Chidester 1992), Chidester published The poetics and politics of sacred space: Towards a critical phenomenology of religion (Chidester 1994). There he critiques the 'sacred' as discussed by Van der Leeuw (cf. Chidester 1994:211-228). In Van der Leeuw's phenomenology, the sacred is discernible because 'power' makes itself felt, and its manifestations are shaped by the human ability to respond to this 'power'. However, Chidester argues that 'power' as a category is problematic in that it attempts 'to replicate an insider's evocation of certain experiential qualities' (Chidester 1994:211). Instead, Chidester turns to the politics of the power that 'the sacred' represents. To explain his new focus, he notes that, in the study of the sacred, both substantial and situational descriptions have been used. The substantial description reflects an engagement with the 'essential experience' of the sacred, while the situational description draws attention to the 'rational politics' of the sacred. In Chidester's opinion, these two descriptions clash and represent what he refers to as a contrast between 'the poetics and the politics of sacred space' (Chidester 1994:212). For Chidester, Van der Leeuw's phenomenology is a poetic kind of 'mystical intuitionism', a poetics that obscures the politics of the sacred. He contrasts this with Durkheim's situational analysis of the sacred, which links the making of the sacred to human social practices (Durkheim 1976). From this Durkheimian perspective, he argues that the term 'sacred' is 'susceptible to the reception of any meaning whatsoever' and is therefore 'nothing more or less than an outcome of cultural labour' (Chidester 1994:211). In Chidester's view, a situational analysis of the sacred ultimately figures the sacred as an 'empty signifier' (Chidester 1994:211), with no intrinsic meaning. This marks a definitive turn in Chidester's phenomenology towards a Foucauldian 'demystifying' of religious phenomena through a critical analysis of power relations. The 'irreducibility' of the sacred is now no longer even bound to the experience of the body, but to be found in the dynamic interplay of human power relations. While this turn is an important one for a field that needed to move away from the biases of $19^{\text {th }}$ - and $20^{\text {th }}$-century ideologies, it involves an almost complete reduction of the term 'sacred' to the interplay of political dynamics within the material world. This would perhaps be less problematic if it did not also rely on an outdated material framework, one which has been profoundly challenged by recent developments in the natural sciences.

The prevailing Cartesian/Newtonian paradigm that configured the world as rational and predictable, proved successful in the $18^{\text {th }}$ and $19^{\text {th }}$ 


\section{Gaelin Meyer}

centuries, as the industrial revolution played out and many natural phenomena were mapped and analyzed. However, this approach to science was challenged from every side during the developments of the $20^{\text {th }}$ century. The early reductionist approach to scientific knowledge had relied on breaking complex phenomena into separate and simpler parts. These parts were then analyzed in an attempt to predict and explain the world. However, this approach failed when being applied to more complex phenomena, like weather patterns, cellular biology, and even social developments. During the $20^{\text {th }}$ century, the emphasis shifted from a study of the parts to a focus on the complexity and interrelatedness of the whole (Laszlo \& Krippner 1998:4). The new paradigm that emerged during this time was concerned with complexity (in the natural sciences) and dynamic intersubjectivity (in the social sciences). Material and social phenomena were understood to be made of complex and interrelated components, often placing them beyond the limits of simply a reductive analysis. This new paradigm was based on a growing understanding of the complex systems that go into constituting our world. Complexity as a paradigm takes over from the limits of the Newtonian tradition. It deals with phenomena as connected, networked, relational, and interdependent, rather than binary, static, and ahistorical. Taking over from the mechanical view, the systems view rejected the idea that the world at large is mechanically ordered and easily available to objective analysis as a whole (Laszlo \& Krippner 1998:15).

The new systemic appraisal of phenomena fed into a new understanding of materiality, a post-modern and post-structural model of a dynamic and self-sustaining material world. In this new approach to materiality, the boundaries between 'matter' and 'social' fall away, as both the material and the social intertwine in a dynamic material engagement (Vásquez 2011:6). In this regard, the new materialism that resulted from the shift in the sciences, presented an immanent materiality, one that needed no metaphysical or supernatural basis. It is this materiality that Chidester begins to explore with his phenomenology of perception. He rejects the $19^{\text {th }}$-century scientific tropes that are based on the Cartesian dualism and essentialism. The entire notion of 'what science does', shifts as the paradigm moves from the mechanical to the systemic towards the end of the $20^{\text {th }}$ century. Chidester's work reflects this paradigm shift, and he attempts to engage religious phenomena with the tools that the late $20^{\text {th }}$ century scientific thinking provides. In this he follows in the footsteps of Chantepie, Van der Leeuw, 
and Smart, who foregrounded the methods of science as the basis for their enquiry into religion. The problem arises through the relatively limited view of 'complex materiality' that Chidester engages in his material phenomenology of religion. For him, materiality is approached as a medium for the human, the lens through which he continues his engagement with 'religion's production and deployment as a category' (Chidester 2018:3).

\section{The Human as the Limit in Material Religion}

In his most recent work Religion: Material dynamics (Chidester 2018), Chidester situates his material approach to religion as an endeavor for 'thinking about the human in the humanities' (Chidester 2018:1). Within this anthropocentric frame is an unexamined humanism in which secular forms of knowledge systems rank higher than non-secular forms. Sonia Hazard (2013) discusses anthropocentricism that is a hallmark of the current material examination of phenomena. She notes that 'things enter the analysis only in so far as they tell us something about human subjects and bodies, which remain the privileged sites of analysis' (Hazard 2013:59). Hazard is championing the relevance of material 'things' in relation to the human focus, but I would suggest that the same argument applies to the non-physical 'things' of religion, the gods, spirits and other-worldly denizens that make up the transcendent epistemological horizons of religious practice.

One of the hallmarks of the religious or non-secular claim is that the human is not epistemologically limited to the known empirical frame, but is able, in some way, to access the unknown 'other'. Furthermore, not only does the 'other' exist as an epistemological opening to something beyond the normal ways of knowing, it even plays an agentic role within the worlds of religious practitioners. This need not be a problem for a non-reductive materiality that is willing to remain open to the epistemological claims that religious practitioners make. The field of material studies is an interdisciplinary success story of the $21^{\text {st }}$ century, but as Bräunlein notes, 'theoretical unity...is lacking, as is agreement over the most appropriate research methods' (Bräunlein 2015:5). The naturalist, positivist materialism that sustained the $19^{\text {th }}$-century sciences has given way to a more complex understanding of material relations. However, anthropocentricism remains one of the ideological positions that forms an obstacle 'to the full realization 


\section{Gaelin Meyer}

of the material turn' (Bräunlein 2015:14). Bräunlein argues that the possibilities of a non-anthropocentric materialism involve an ontological turn ${ }^{9}$ that challenges 'the subject-object and nature-culture divides and, in their radical variants, postulate a "point of view" of nonhumans, be they animals, spirits, plants, or even microbes' (Bräunlein 2015:24).

In Chidester's attempt to 'move away from the old metaphysical divide between spirit and matter' (Chidester 2018:14), he also makes the assumption that a form of metaphysical instability is 'retained by new materialists attributing spirit, vibrancy, or agency to material objects' (Chidester 2018:14). Rather than exploring the dynamic epistemological potentials of claims regarding spirit, vibrancy, or agency, he limits his discussion to the political economy around that which is deemed 'religious'. This is an important contribution to the study of religion, particularly in light of the social and political inequalities that $19^{\text {th }}$-century religious studies helped to propagate. However, it does not take the examination of religion far enough towards a comprehensive account of religious phenomena. It is necessary but not sufficient. Chidester aims to uncover 'the ways in which things rise to the level of materiality by making a material difference in the world' (Chidester 2018:210). This aim is resonant with an approach that allows for the actions of religions' 'others', while still relying on a material appraisal of phenomena. By allowing for the potential existence of 'spirit, vibrancy, and agency' within his political appraisal of material religion, he would have a relevant and useful platform to discuss the role and significance of the many religious 'others' that populate the social and religious spaces of the world.

He rejects the agency of non-human actors as a protective measure, suggesting that, when engaging dynamic and complex material studies, 'the being of human being is at stake' (Chidester 2018:207). However, a step beyond the epistemological bounds of humanism does not mean a complete defocusing on the human; it rather points to a re-situating of the human. It is not an eliminative process, but an affirmative one (Braidotti 2013:38), not an anti-humanism but a 'posthumanism'9 that works 'towards elaborating

9 Ontologies are discourses around the nature of being. In particular, the Western ontological position has, in modern times, revolved around humanist ideals: The human as the privileged center of being and knowing. The turn referred to by 
alternative ways of conceptualizing the human subject ${ }^{10}$ (Braidotti 2013:37). In this regard, a critical rethinking of the anthropocentric bias in the material phenomenology of religion is not a form of anti-human rhetoric, but a call to examine the possibilities that are occluded when the 'human' forms the limits of knowledge. Chidester, by centering his examination of religious phenomena on the politics which play out within human material relations, places 'the human' as the epistemological limit in his enquiry.

Andrew Pickering, a sociologist, philosopher, and historian of science at the University of Exeter, writes about the epistemological limits of modern science. He discusses the case of the Yanomami, who work as Shamans and mediate between their people and the xapiri spirits, which form part of their epistemological and ontological framework. When approaching people who are immersed in alternate epistemological frameworks, there are problems for a study of religion that locates itself wholly in natural, secular enquiry, as 'modern science has no resources for imagining that xapiri spirits exist. They can at most be some sort of projections onto nature by the Yanomami' (Pickering 2017:11). This reframing of the epistemological stance to fit the naturalist perspective may be viewed by contemporary scholars as progressive, as a move from the pre-secular to the secular, reflecting the usefulness of modern science as it dispels the impossible beliefs of the cultural others that it engages (Pickering 2017:12). However, one should bear in mind that this kind of hegemonic bias is what early material religionists like Chidester are expressly attempting to avoid. As long as the secular science of religion seeks to exclude non-secular or non-modern epistemologies, the hegemony continues. As Pickering notes, to take non-secular positions seriously 'requires somehow crediting that which should not be credited' (Pickering 2017:14) and puts the scholar in a difficult position.

Bräunlein involves a repositioning of the human being to a coexistent field within a matrix of relations, rather than the privilege of a hierarchically defined significance.

10 The term 'posthuman' has a complex history, stemming from a post-structuralist and often anti-human heritage (Braidotti 2013:16). The way in which Braidotti uses this term is an affirmative usage, i.e., she is not anti 'the human' as a designation, but pro a reworking of this concept from the ground up, with particular attention paid to the implicit Eurocentric biases to be found when modern 'humanism' is engaged. 


\section{Gaelin Meyer}

However, this difficult position can be mitigated by a purposeful positioning within a space that allows for the descriptive input of religious insiders to be accepted without upfront contention around truth values. How this positioning is negotiated, the conditions of the 'examination', and the tenuous standing of the 'objective' researcher, are issues which have yet to be satisfactorily resolved.

Yet we do have some good pointers. In Chidester's work on Zulu dreaming in Southern Africa, he discusses the contact zones that form in the overlap between cultures during times of colonial conquests. He describes these material/cultural zones of contact as places of both insight and conflict, of 'transcultural relations and asymmetrical power relations' (Chidester 2008: 27). New practices emerge in these spaces, reflecting the cultural heritages of both the oppressor and the oppressed. His overview of the political dynamics around cultural conflict has helped contemporary scholars to make sense of the damaging categories and practices that formed during the early British occupation of Southern Africa, as well as more recently during the years of the National Party rule. Perhaps it is time to address the contact zones that arise as a matter of course between the different epistemological positions of the religious believers and the religious scholar. Within these epistemological contact zones, new rules apply, which forbid the outright rejection of any claims to knowledge. Without committing to either a secular or a non-secular frame, the scholar who examines the contact zone of overlapping 'ways of knowing' has an intriguing and relevant way of accessing religion.

Matthew Day, an associate Professor of Religion at Florida State University, writes about 'the labor required to make the gods and spirits real actors' (Day 2010:272). He bases his approach on the work of Bruno Latour, a French philosopher, anthropologist, and sociologist. Latour suggests that, in the study of religion, 'what counts are the beings that make people act, just as every believer has always insisted' (Latour 2005:235). Day takes this idea further and insists that the 'entities' posited by religious insiders are

not ciphers for 'Society' (e.g., Durkheim), 'Culture' (e.g., Geertz), or 'Economy' (e.g., Marx). They are rather some of the many nonhuman actors who circulate within a given network: agents who make their presence felt by sharing the labor required to gather, attach, move, motivate or bind their fellow actors together (Day 2010:278). 
In this regard, Day is approaching an epistemological overlap, a contact zone at the point where secular science meets religious insiders' positions. The response from the material study of religion could be to re-engage insider and theological perspectives and replace eliminative ontologies with something like agnostic-positive ontologies, bracketing in rather than bracketing out unknowns. This would then be an engaging with pre-modern and non-modern beliefs and cosmologies, in a move that would help to position 'post-secular', yet non-theological, religious studies.

Braidotti (2013:35) discusses the 'post-secular approach' that grows out of a rejection of the humanist ideas around secularity and rationality. She suggests that the West is experiencing a 'crisis of secularism' (Braidotti 2013:36) in which a belief in the axioms of secular science is being challenged. As Jay Johnston notes in his contribution to the book, Making religion (Johnston 2016), 'esoteric, vernacular, and indigenous practices (for example, ritual, magic, and forms of spiritual healing) rely on different orders of logic than those tied to or emerging from empirical observation of direct cause and effect' (Johnston 2016:77). Furthermore, he reminds the reader that 'what counts as "reason" itself is neither static nor universal' (Johnston 2016:80). The secular framework which accepts only limited forms of empirical reason as legitimate must, in some cases, make way for an 'epistemological simultaneity - that is, the recognition that multiple modes of knowing work concurrently, and furthermore, that there is an ethical imperative to develop skills in recognizing the operations of all of these modes of thought, including non-dominant, rejected (and often ridiculed) forms' (Johnston 2016:80).

In this regard we need to rethink the wholly secular position of the material study of religion. Earlier phenomenological approaches in the study of religion endeavored to acknowledge the epistemological and ontological positions of religious insiders and avoided a purely naturalistic account. The acceptance of different 'ways of knowing' is pivotal in defending and defining a comprehensive study of religion. This need not involve a step back from the materialist turn, but rather a modification of the material framework that Chidester suggests. The $21^{\text {st }}$ century opens up conversations around epistemology and ontology that expand the horizons of modern science in new and provocative ways. In this day and age, the idea that a study of religion could be open to the epistemological possibilities of non-secular thought is not that strange at all. The religious insider is continually faced 


\section{Gaelin Meyer}

with this double bind within modern culture. There is a consistent 'crosspressure' experienced by the modern individual, who is presented with evidence towards secular scientific reasoning that dismisses other forms of knowledge making, while also experiencing 'the solicitations of the spiritual' (Taylor 2007:360). In this regard, many religious insiders already entertain dual epistemologies, with commitments both to scientific reason and faith in religious revelation, even though this position is perhaps always tenuous and contestable. Day (2010) urges scholars of religion to consider that the naturalist strategy, which would reinterpret the experience of religious insiders to fit within the limits of a relatively bounded materiality, is also a strategy of marginalization. The truth claims of religious insiders may not be measurable by the methods of science, but this does not mean that these truth claims should be reduced away to the more manageable phenomena of a material culture. A science which is honestly interested in the experience of religious others cannot afford to foreclose on the possibility that religion does indeed reflect a unique ontological and epistemological position.

\section{Conclusion}

Chantepie, Van der Leeuw, and Smart all attempted to negotiate a position between the transcendent frame of Western theology and the immanent frame of Western science. This forms the basis for their comparative method in secular religious studies. For these early thinkers the epistemological juxtaposition is necessary, as it marks an attempt towards a study of religion that remains relevant to religious believers, while also satisfying the criteria of a secular science. They present a secular field of study that is only achievable through an epistemological tension between the insider's and the outsider's position. This is field defining: Classical phenomenology of religion requires a dual commitment to a scientific method and religious irreducibility.

Moving the project forward, Chidester's phenomenology defends the 'domain-preserving' kind of irreducibility that preserves religion as a unique area of enquiry within the secular academy and thus does not radically move the field onto new ground in this regard. However, the second type of irreducibility, the metaphysical irreducibility that reflects categories which are of relevance to theological thought and religious insider practice, is eventually abandoned in his move to the material. Chidester presents a 
version of materiality that resolves the longstanding epistemological juxtaposition by relocating the 'irreducibility' of religion into a bounded material/political dynamic. In this regard, he is performing a radical ontological reduction of the category of 'religion' itself. The question remains whether one can still lay claim to a comprehensive description of religion under these conditions. Religion is reduced to the limited domain of materialpolitical interactions, while the epistemological and ontological possibilities offered by non-secular and theological discourses are rejected. Furthermore, the material-political domain is defined and examined in relation only to 'the human', reflective of a certain way of thinking and reasoning particular to the modern secular mind. This is problematic for $21^{\text {st }}$-century scholars of religion who are sensitive to the differences in epistemological positions that they encounter in the world.

The limits imposed by a material religion's anthropocentric bias can be overcome. The current post-human discourse decentralizes the notion of 'the human', placing us as a contingent part of a wider and more complex system, rather than at the center. First, we believed that God was the center of the universe, then we believed that our planet was the center of the universe. Now many of us are under the illusion that the human species forms the center of any relevant universe we may care to explore. By looking beyond the limits of humanism, by accepting that 'the human' may not be the measure of all things, the secular conversation around religion may be more amenable to engaging the beyond-human, more-than-human religious 'other' that forms the focus of so much religious experiences and practices.

\section{References}

Bräunlein, P.J. 2016. Thinking religion through things: Reflections on the material turn in the scientific study of religionls. Method and Theory in the Study of Religion 28, 4/5: 365-399.

Braidotti, R. 2013. The posthuman. Cambridge: Polity Press.

Chantepie de la Saussaye, P.D. 1891. Manual of the science of religion. London: Oxford Press.

Chidester, D. 1992. Word and light: Seeing, hearing, and religious discourse. Urbana: University of Illinois Press. 
Chidester, D. 1994. The poetics and politics of sacred space: Towards a critical phenomenology of religion. In Tymieniecka A.-T. (ed.): From the sacred to the divine: A new phenomenological approach. Analecta Husserliana: The yearbook of phenomenological research. Vol. XLIII. Dordrecht: Kluwer.

Chidester, D. 1996. Savage systems: Colonialism and comparative religion in Southern Africa. Charlottesville: University Press of Virginia.

Chidester, D. 2008. Dreaming in the contact zone: Zulu dreams, visions, and religion in nineteenth-century South Africa. Journal of the American Academy of Religion 76, 1: 27-53.

Chidester, D. 2018. Religion: Material dynamics. Berkeley: University of California Press.

Day, M. 2010. How to keep it real. Method and Theory in the Study of Religion 22: 272-282.

Durkheim, É. 1976. The elementary forms of the religious life. $2^{\text {nd }}$ ed. Swain, J. (trans.). London: Allen \& Unwin.

Hazard, S. 2013. The material turn in the study of religion. Religion and Society: Advances in Research 4, 58-78.

Johnston, J.M. 2016. Slippery and saucy discourse: Grappling with the intersection of 'alternate epistemologies' and discourse analysis. In Wijsen, F. \& K. von Stuckrad (eds.): Making religion, theory and practice in the discursive study of religion. Leiden: Brill.

Latour, B. 2005. Reassembling the social: An introduction to actor-networktheory. New York: Oxford University Press.

Laszlo, A. \& S. Krippner 1998. Systems theories: Their origins, foundations, and development. In Jordan, J.S. (ed.): Systems theories and a priori aspects of perception. Amsterdam: Elsevier Science.

Merleau-Ponty, M. 1962. Phenomenology of perception. Smith, C. (trans.). London: Routledge.

McCutcheon, R.T. 1999. General introduction. In McCutcheon, R.T. (ed.): The insider/outsider problem in the study of religion: A reader. London, New York: Continuum.

Pals, D. 1999. Reductionism and belief: An appraisal of recent attacks on the doctrine of irreducible religion. In McCutcheon, R.T. (ed.): The insider/outsider problem in the study of religion: A reader. London, New York: Continuum. 
Pickering, A. 2017. The ontological turn: Taking different worlds seriously. Social Analysis 61 (2): 134-150.

Robison, J. 1798. Philosophy. In Gleig, G. (ed.): Encyclopedia Britannica. $3^{\text {rd }}$ ed. Edinburgh: Thomson Bonar.

Smart, N. 1973. The science of religion and the sociology of knowledge: Some methodological questions. Princeton: Princeton Legacy Library.

Smart, N. 1978. The phenomenon of religion. London: Macmillan.

Smart, N. 1986. Foreword. In Van der Leeuw, G (ed.): Religion in essence and manifestation. $2^{\text {nd }}$ ed. Turner, J. (trans.). New York: Harper and Row.

Smart, N. 1996. Dimensions of the sacred: An anatomy of the world's beliefs. Berkeley: University of California Press.

Taylor, C. 2007. A secular age. Cambridge: Harvard University Press.

Tylor. E.B. 1920. Primitive culture: Researches into the development of mythology, philosophy, religion, language, art, and custom. Vol. 1. $5^{\text {th }}$ ed. London: John Murray.

Van der Leeuw, G. 1986. Religion in essence and manifestation. $2^{\text {nd }}$ ed. Turner, J. (trans). New York: Harper and Row.

Vásquez, M. 2011. More than belief: A materialist theory of religion. Oxford, New York: Oxford University Press.

Gaelin Meyer

Graduate Student Department of Religious Studies University of Cape Town gaelinmeyer@me.com 